\title{
A Macro Seismic Hazard Zonation for Sri Lanka
}

\author{
H.N. Seneviratne, K.K. Wijesundara, L.R.K. Perera and P.B.R. Dissanayake
}

\begin{abstract}
This paper describes the outcome of a comprehensive study carried out to analyse the seismic hazards affecting Sri Lanka. The main seismic threat is from oceanic earthquakes originating at failed Mannar rift zone and Comorin ridge off the west to south west coast with some secondary influence from South Indian crustal earthquakes. The analyses were performed using Deterministic Seismic Hazard Assessment, Probabilistic Seismic Hazard Assessment and seismic wave propagation using FLAC software ignoring the overburden attenuation within the landmass. The seismic scenario included 100 years earthquake catalogue with an characteristic earthquake of magnitude 6.9 at a distance $90 \mathrm{~km}$ from the west coast. Historical records of earthquakes in the vicinity of Sri Lanka indicate that 1615 earthquake was the most significant earthquake that affected Sri Lanka. The analyses show that South West to North West coastal areas are the most vulnerable to seismic hazards. There is also reflection of seismic waves leading to amplification of seismic waves in the central highland.

Based on the analyses described above, a seismic hazard map for Sri Lanka dividing the country into two zones of seismic intensity and response spectrum is provided accordingly. The study was constrained by the lack of recorded data of past earthquake responses within the country and a network of seismic stations are proposed in the paper for future data collection.
\end{abstract}

Keywords: Mannar rift zone, Gutenberg-Richter relationship, Response spectrum

\section{Past Seismic Activities close to Sri Lanka}

The earliest documentary record of an earthquake affecting Sri Lanka is based on a pamphlet published in Lisbon in 1616 describing an event which took place on 14 April 1615 near Colombo (Gunasekara, 2000) [9]. This record is described in detail bySeneviratne et al. (2019) [17]. Even though the original paper is not very scientific and contains many religious interpretations, there are many interesting facts which can be extracted.

In the period preceding the main event, there are accounts of:

"Dead fish thrown up from the sea so poisonous that people who ate them died. The atmosphere most infected with Putrefaction and bad odour which killed people and birds. People were scared to go to the sea side let alone bathing as those who did were fallen sick".

The above facts are consistent with gas release through the seabed, which is a possible activity in the active Mannar rift zone.

"On the day of earthquake, the sun set half an hour earlier than on other days".

The logical explanation for this may be a gas emission at the source of tectonic activity rising up in the atmosphere blocking the sun. If this is correct, the tectonic activity occurred approximately in the direction of west of Colombo. The distance to the activity is proportional to the height of the clouds at the time of sunset, which can be calculated using basic geodetic principles.

"It was seven in the evening when thunder shook the air with such force and the earth quaked so violently that, unable to remain in the houses people rushed out to the streets fearing to be buried under the falling ruins of the buildings. Then bolts of thunder fell from the heavens. The thunderbolts had their effect, destroying and laying low not only the most sumptuous edifices but also the meanest cottages leveling all, and the few that the fire had not consumed were destroyed by the earthquakes".

Thunder, lightning and fire have been commonly observed in such earthquakes in the past, according to literature. The number of casualties has been stated as 2000 with many houses destroyed and wide deep cracks visible on the ground.

Eng. (Prof.) H.N. Seneviratne, FIE(SL), BScEng (Ceylon), PhD (Cambridge), Senior Professor, Department of Civil Engineering, University of Peradeniya.

Email:nimalseneviratne1@gmail.com

(10) https://orcid.org/0000-0001-5352-2652

Eng. (Dr.) K.K. Wijesundara, AMIE(SL), BScEng (Peradeniya), MSc (Pavia), PhD (Pavia), Senior Lecturer, Department of Civil Engineering, University of Peradeniya. Email:kushanw@pdn.ac.lk

(10) https://orcid.org/0000-0002-4174-8707

Mr. L.R.K. Perera, BSc (Peradeniya), MPhil (Peradeniya), Senior Lecturer, Department of Geology, University of Peradeniya.

Eng. (Prof.) P.B.R. Dissanayake, C. Eng., FIE(SL), BSc

Eng. (Hons) Peradeniya), MSc (Ehime), PhD (Ehime), Senior Professor, Department of Civil Engineering, University of Peradeniya.

Email:ranjith@pdn.ac.lk

(1D) https://orcid.org/0000-0003-2296-8947 
Based on the damage, the magnitude of the earthquake can be estimated as 6.5 with epicenter close to Colombo.

No other earthquake of similar magnitude has occurred since then. However, there had been a number of seismic events, particularly the events in 1938 and 1940, which were felt in many parts of the island though no casualties or significant damage had occurred. The 1938 earthquake was felt strongly in the western province and central highland, but not so much in eastern province. Within Sri Lanka, very little seismic activity (3 - 3.5 Richter scale) has been recorded (Fernando and Kulasinghe, 1986) [7]. No major seismic activity has been recorded coming from south east and north of Sri Lanka in the recent past except the Tsunami caused by 2004 earthquake (Sunda trench earthquake).

\section{Geological Setting of Sri Lanka}

Sri Lanka is located in the North Western region of the Indo-Australian plate. The interplate seismic activity around this plate is governed by Himalayas to the north on which it pushes against the Euroasian plate and by Sunda trench to the east on which it undergoes subduction causing earthquakes and tsunamis. The seismic activity to the far west at the midIndian ocean ridge and to the south are less significant in comparison to the above, as the former are zones of crustal extension compared to zones of compression in the north and east. However, some seismologists discuss the possibility of the emergence of a new plate boundary to the south of Sri Lanka (Dissanayake, 2005) [6]. The above interplate events are not considered significant as far as Sri Lanka is concerned (Thaldena et al. 2013) [20] but the tsunami hazard due to seismic activity at the Sunda trench is considerable.

In the present study, the intraplate activities spanning northwest to southwest coast of Sri Lanka in the vicinity of failed Mannarrift zone and the Comorin ridge which were not hitherto considered important are analysed in detail. This is particularly important considering the heavily populated and economically important areas near the west coast and/or within western province. The intraplate activities originating in the other regions around Sri Lanka are not considered important except to the north where intraplate seismic activity in South India may have some influence on the northern region of Sri Lanka. The intraplate seismic activity within Sri Lanka appears to be not significant (Fernando and Kulasinghe, 1986) [7].

\section{Geological Significance of Failed Mannar Rift Zone and Comorin Ridge}

Sri Lanka is believed to be geologically the southern continuation of peninsular Southern India although the island today is separated from the mainland India by a narrow stretch of shallow sea. This stretch of the sea is now a part of the Indian Ocean, but it opened-up as Sri Lanka drifted apart from India at the time the super continent Gondwana broke-up during the Jurassic period (Curray, 1984; Baillie et al. 2002; Kularatne et al. 2015) [5], [3], [11]. Continued rifting of continents always leads to formation of large ocean basins but it produces narrow seas or inland lakes at initial stages. Rifting produces faulted blocks of rocks with the faulting extending laterally for tens to hundreds of kilometers, and vertically downward to the mantle, providing pathways for rising magma. Zones of initial rifting therefore, are always geologically very active as they are sites of active volcanism and seismicity.

The narrow sea between Sri Lanka and South India however, is a failed rift zone; this is the underlying reason for the absence of active volcanism and seismicity today. However, the Cauvery and Mannar basins produced by the rifting process is floored by faulted blocks of continent and sedimentary successions which are about 10 kilometers thick, laid down on the faulted sea floor since the Cretaceous period. During exploratory drilling for oil in the Cauvery and Mannar basins, frozen basaltic lava flows have been encountered (Rana et al. 2008) [15]. These are inter-layered with sediments indicating that the rift zone had been volcanically and seismically active in the past.

Seismic exploration of the sedimentary succession in the Cauvery and Mannar basins has indicated relative disposition of faulted blocks of rocks on the basin floor. As the sediment load increases one cannot rule-out reactivation of the fault zones and relative motion between the already faulted blocks of rocks generating some seismicity. In the Bay of Bengal to the east and northeast of Sri Lanka, there is also evidence of sea floor spreading. The settling of sedimentary successions has given rise to earthquakes with magnitude around M5 in the recent past, the latest being in 
April 2009. Although highly active seismic zones are quite far away from Sri Lanka, the potential of the above sedimentary basins to the NW and NE of Sri Lanka becoming foci of future low magnitude earthquakes (up to M6) has to be borne in mind. However, the seismic status of Sri Lanka is dominated by failed Mannar rift zone and Comorin ridge (NW basin) as very few significant seismic activities have been recorded in the NE basin.

\section{Seismic Monitoring in and around Sri Lanka}

A Milne seismograph was installed in Colombo Observatory in 1909. This was replaced by a Milne-Shaw seismograph in 1927. The observations from this seismograph had been connected to a global network comprising 350 seismographic stations. The original records are kept at the Department of Meteorology which succeeded the Colombo Observatory in 1972. Therefore, measured earthquake data at Colombo should be available from 1909-1992. Unfortunately however, no data from seismograph at Colombo observatory are available since 1992 as the seismograph was not in a fully functional condition.

Three seismometers were installed by Geological Survey and Mines Bureau (GSMB), one in 2000 at Pallekele (PALK) connected to Global Seismographic Network (GSN), and the others in 2010 at Mahakandarawa (MALK) and Hakmana (HALK), connected to GEOFON Network. The waveform data and earthquake parameters from these seismometers are available through the internet from the GSN and GEOFON networks through GSMB.

The major problem of seismic monitoring of Sri Lanka performed in the past by government agencies is the lack of monitoring data available throughout the island. This is normally facilitated by having a series of seismometers at strategic locations. Up to date no such network has been established.

\section{Earthquake Catalogue for Intraplate Seismicity in and around Sri Lanka}

Early earthquake catalogues on the seismicity around Sri Lanka were prepared by Vitanage (1995) [22] and Abayakoon (1996) [1]. In addition, a number of Indian catalogues cover many earthquakes in the South Indian region (Menon et.al., 2010) [13]. In the present study to investigate the seismicity around Sri Lanka, an area bounded by Latitude $0^{\circ} \mathrm{N}-20^{\circ} \mathrm{N}$ and Longitude $70^{\circ} \mathrm{E}-90^{\circ} \mathrm{E}$ was selected (see Figure
1). The records from Abayakoon (1996) [1]. and Uduweriya (2014) [21] are based on the data reported by many global data bases such as IRIS data base. The data which goes back to 1063 A.D. consisting of past seismographic observations, and estimations based on damage intensity or from paleo-seismological studies, was used in preparation of the catalogue.

The epicenters of the earthquakes taken from the catalogue are illustrated in Figure 1.

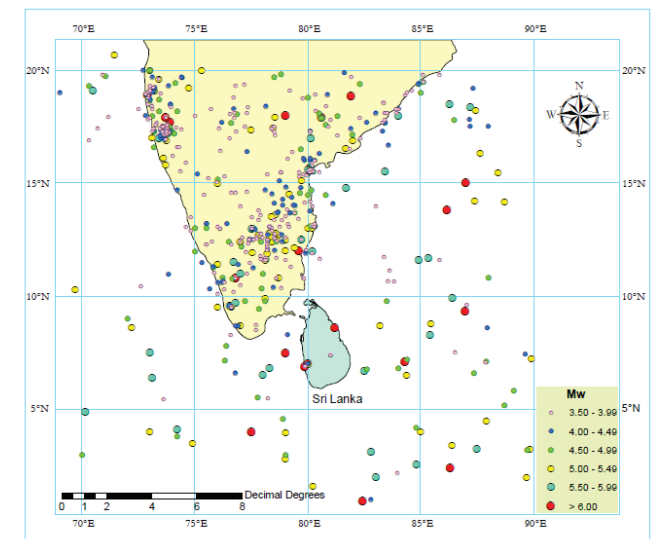

Figure 1 - Epicenters from Past Earthquakes

It is clear from Figure 1 that a high intensity earthquake zone is concentrated along the NE, SW Indian fault zone going from Ongole to Kerala. However, this fault region is far away from Sri Lanka to have any significant impact on the seismic status of Sri Lanka except in the northern region.

The seismic status close to Sri Lanka appears to be governed by the activities in the western coastal region in which failed Mannar rift zone and Comorin ridge can be easily identified as the main tectonic features. This is very clearly visible in Figure 2, which shows the filtered version of the catalogue (Catalogue B) created by narrowing down the original area to $3.5^{\circ} \mathrm{N}$ $8.5^{\circ} \mathrm{N}$ and $75^{\circ} \mathrm{E}-80^{\circ} \mathrm{E}$ window.

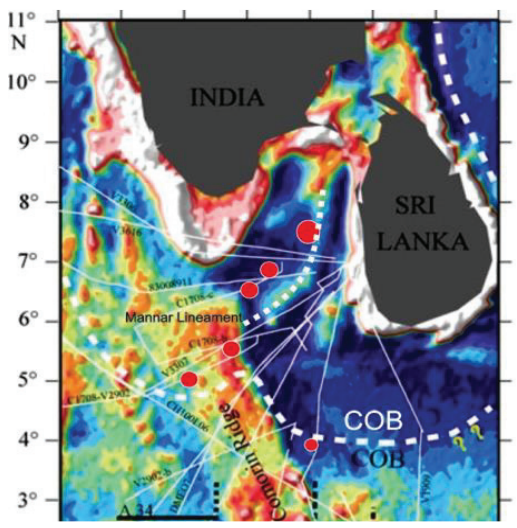

Figure 2 - Epicentres of the Earthquake Occurred on the Comorin Ridge and the Surrounding Area (Structure and Isostatic Compensation of the Comorin Ridge, North Central Indian Ocean by Sreejith et al. 2008) [18]. 
The seismic activities in the other coastal regions of the catalogue $\mathrm{A}$ appear to be insignificant in comparison according to the available data at present. The completeness of this catalogue has been tested according to the procedure described by Stepp (1973) [19]. It shows that 100 years data is sufficient for the completeness (Seneviratne et al., 2019) [17].

\section{Analysis of Seismicity of Sri Lanka}

Three types of analyses, namely DSHA (Deterministic SeismicHazard Analysis), PSHA (Probabilistic Seismic Hazard Analysis) and numerical analysis using finite difference FLAC software, were performed. Considering the geology of Comorin Ridge and Failed Mannar rift zone, a characteristic earthquake of 6.9 moment magnitude occurring at a distance of $90 \mathrm{~km}$ from NW-SW coastal line was chosen for the DSHA and the finite difference analysis. PSHA was performed using the complete earthquake catalogue.

\subsection{Deterministic Seismic Hazard Analysis (DSHA)}

DSHA predicts the seismic response (defined by peak ground acceleration (PGA) at a point, distance D away from the seismic source, based on an attenuation relationship available in the literature derived using observed data from seismic sources elsewhere (Reiter (1990) [16]. For the seismic scenario given above, two attenuation relationships available in the literature (Gitterman et al. 1993) [8] , and KunSung and Yi-Ben, 2005) are calibrated against the monitoring data from GMSB for an earthquake of magnitude of 4.7 at a distance of $270 \mathrm{~km}$ from the western coastal line. The comparison showed that Gitterman et al. (1993) [8] gives the most suitable relationship for calibration data. The prediction for the given seismic scenario (6.9 magnitude at $90 \mathrm{~km}$ ) given by Gitterman et al. (1993) [8] for selected locations within Sri Lanka are given in Table 1.

\subsection{Probabilistic Seismic Hazard Analysis}

PSHA was performed by considering eleven seismic zones in and around Sri Lanka. The complete earthquake catalogue from 1900 to present were used in the analysis. Three attenuation relationships: Abrahamson and Silva (1997) [2], Cambell and Bozorgnia (2008) [4] and Raghukanth and Iyenger (2007) [14] suitable for the whole region under consideration were used in the analysis. The prediction of PGA and Spectral Acceleration (SA) at point of interest within Sri Lanka were performed considering all zones. In each zone, the magnitude $M$ of 475 year return period earthquake was calculated considering all past earthquakes within that zone. This earthquake was placed on the boundary of the zone closest to the point of interest and the PGA and SA at the point was calculated for magnitudes of $M$ and $\mathrm{M}+0.3$ using three attenuation relationships.

Table 1 - PGA Values at Selected Cities in Sri Lanka

\begin{tabular}{|l|c|c|}
\hline \multirow{2}{*}{\multicolumn{1}{|c|}{ City }} & \multicolumn{2}{|c|}{ PGA (g) } \\
\cline { 2 - 3 } & $\begin{array}{c}\text { M=6 at 15 } \\
\mathbf{k m}\end{array}$ & $\begin{array}{c}\mathbf{M = 6 . 9} \text { at 90 } \\
\mathbf{k m}\end{array}$ \\
\hline Ampara & 0.004 & 0.006 \\
\hline Anuradhapura & 0.007 & 0.009 \\
\hline Badulla & 0.01 & 0.013 \\
\hline Batticaloa & 0.004 & 0.005 \\
\hline Colombo & 0.132 & 0.067 \\
\hline Dambulla & 0.009 & 0.012 \\
\hline Gampaha & 0.108 & 0.062 \\
\hline Galle & 0.016 & 0.019 \\
\hline Hambantota & 0.007 & 0.009 \\
\hline Horana & 0.08 & 0.054 \\
\hline Jaffna & 0.002 & 0.002 \\
\hline Kalutara & 0.061 & 0.047 \\
\hline Kandy & 0.018 & 0.021 \\
\hline Kurunegala & 0.023 & 0.025 \\
\hline Mannar & 0.003 & 0.005 \\
\hline Matara & 0.011 & 0.013 \\
\hline Negombo & 0.083 & 0.055 \\
\hline Nuwara Eliya & 0.016 & 0.019 \\
\hline Polonnaruwa & 0.007 & 0.009 \\
\hline Puttalam & 0.012 & 0.015 \\
\hline Rathnapura & 0.034 & 0.033 \\
\hline Trincomalee & 0.003 & 0.004 \\
\hline Vavuniya & 0.004 & 0.006 \\
\hline
\end{tabular}

The epistemic uncertainties were dealt with by logic tree approach. The results of PSHA thus obtained for the selected locations in Sri Lanka are shown in Table 2.

\subsection{Finite Difference Analysis using FLAC Software}

FLAC is a general purpose finite difference software which can solve wave propagation equations in linear elastic media. A typical two dimensional cross section used for analysis is illustrated in Figure 3.

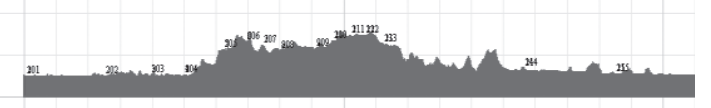

Figure 3 - Model Cross Section Developed for the Section Passing through ColomboBatticaloa 
Table 2 - PGA at Different Cities in Sri Lanka for 50, 475 and 2475 Year Return Periods

\begin{tabular}{|l|c|c|c|}
\hline \multirow{2}{*}{ City } & \multicolumn{3}{|c|}{ PGA (g) } \\
\cline { 2 - 4 } & $\mathbf{T}=\mathbf{5 0}$ & $\mathbf{T}=\mathbf{4 7 5}$ & $\mathbf{T}=\mathbf{2 4 7 5}$ \\
\hline Ampara & 0.002 & 0.011 & 0.027 \\
\hline Anuradhapura & 0.007 & 0.034 & 0.074 \\
\hline Badulla & 0.003 & 0.017 & 0.04 \\
\hline Batticaloa & 0.002 & 0.011 & 0.028 \\
\hline Colombo & 0.025 & 0.107 & 0.207 \\
\hline Dambulla & 0.004 & 0.025 & 0.056 \\
\hline Galle & 0.009 & 0.045 & 0.094 \\
\hline Hambantota & 0.003 & 0.016 & 0.038 \\
\hline Horana & 0.013 & 0.062 & 0.127 \\
\hline Jaffna & 0.041 & 0.158 & 0.325 \\
\hline Kandy & 0.005 & 0.025 & 0.057 \\
\hline Kurunegala & 0.007 & 0.035 & 0.076 \\
\hline Mannar & 0.033 & 0.134 & 0.28 \\
\hline Matara & 0.005 & 0.028 & 0.061 \\
\hline Mullaitivu & 0.008 & 0.04 & 0.101 \\
\hline Nuwara Eliya & 0.004 & 0.022 & 0.05 \\
\hline Polonnaruwa & 0.003 & 0.018 & 0.042 \\
\hline Puttalam & 0.029 & 0.122 & 0.233 \\
\hline Rathnapura & 0.006 & 0.033 & 0.073 \\
\hline Trincomalee & 0.009 & 0.026 & 0.048 \\
\hline
\end{tabular}

The western and eastern boundaries are the continental shelf of Sri Lanka taken along the five cross sections: Colombo-Batticaloa, Kalutara-Kalmunai, Galle-Arugambay, ChilawVakarei, and Puttalum-Trincomalee. The vertical dimensions of the cross sections were taken from the 1:50000 survey map of Sri Lanka ignoring the overburden. The dynamic material properties for the analysis were taken from Jayawardene (2010) [10], which contains the results for a large number of samples. Test runs with the model indicated that all three boundaries (two sides and the base) should be wave absorbent type. The characteristic depth of all the sections was taken $10 \mathrm{~km}$ from the mean sea level. In the absence of any measured data, PGA and SA at the western boundary were taken as the average of seven earthquakes data taken from PEER data base having approximately similar magnitude and distance to point of interest.

The results of this analysis are also presented in Table 3. It can be observed an interesting effect that the PGA is amplified in some hilly areas.

Table 3 - PGA Values at Selected Cities in Sri Lanka

\begin{tabular}{|c|l|c|}
\hline No. & \multicolumn{1}{|c|}{ City } & PGA (g) \\
\hline 1 & Galle & 0.080 \\
\hline 2 & Kottawa & 0.063 \\
\hline 3 & Akuressa & 0.059 \\
\hline 4 & Pasgoda & 0.065 \\
\hline 5 & Katuwana & 0.068 \\
\hline 6 & Panamure & 0.062 \\
\hline 7 & Angunakolapalassa & 0.044 \\
\hline
\end{tabular}

\begin{tabular}{|c|c|c|}
\hline 8 & Weheragala & 0.036 \\
\hline 9 & Andiawela & 0.029 \\
\hline 10 & Arugam Bay & 0.023 \\
\hline 11 & Kaluthara & 0.082 \\
\hline 12 & EgalOya & 0.060 \\
\hline 13 & Idangoda & 0.053 \\
\hline 14 & Kuruwita & 0.047 \\
\hline 15 & Thummodara & 0.050 \\
\hline 16 & Nallathanniva & 0.058 \\
\hline 17 & Maskeliya & 0.060 \\
\hline 18 & Hatton & 0.051 \\
\hline 19 & Lindula & 0.047 \\
\hline 20 & NanuOya & 0.040 \\
\hline 21 & NuwaraEliva & 0.045 \\
\hline 22 & Kandapola & 0.042 \\
\hline 23 & Ragala & 0.044 \\
\hline 24 & Bibile & 0.031 \\
\hline 25 & Kalmunai & 0.024 \\
\hline 26 & Colombo & 0.083 \\
\hline 27 & Ussapitiva & 0.060 \\
\hline 28 & Kandy & 0.048 \\
\hline 29 & Narampanawa & 0.044 \\
\hline 30 & Knuckles1 & 0.040 \\
\hline 31 & Meemure & 0.041 \\
\hline 32 & Knuckles & 0.037 \\
\hline 33 & Batticaloa & 0.021 \\
\hline 34 & Chilaw & 0.083 \\
\hline 35 & Ella & 0.068 \\
\hline 36 & Migaswewa & 0.058 \\
\hline 37 & Thalpathwewa & 0.057 \\
\hline 38 & Alutwegedara & 0.056 \\
\hline 39 & Bulanwewa & 0.048 \\
\hline 40 & Dambulla & 0.045 \\
\hline 41 & Kandalama & 0.043 \\
\hline 42 & Kaduruwela & 0.034 \\
\hline 43 & Tambala & 0.033 \\
\hline 44 & Vakarai & 0.025 \\
\hline 45 & Puttalam & 0.095 \\
\hline 46 & Balagollagama & 0.080 \\
\hline 47 & Saliyawewa & 0.074 \\
\hline 48 & Anuradhapura & 0.050 \\
\hline 48 & Mihinthale & 0.047 \\
\hline 50 & Tammanewa & 0.044 \\
\hline 51 & Amunukola & 0.038 \\
\hline 58 & Trincomalee & 0.027 \\
\hline 53 & Ambagahawewa & 0.038 \\
\hline 54 & Katupotana & 0.034 \\
\hline 55 & Nagollewa & 0.032 \\
\hline 56 & Palampoddaru & 0.029 \\
\hline 57 & Ganeshapuram & 0.027 \\
\hline 58 & Trincomalee & 0.027 \\
\hline
\end{tabular}

\section{Seismic Hazard Map for Sri Lanka}

The results of DSHA, PSHA and finite difference analyses are reasonably consistent. This may be due to the fact that the dominant seismic source for all three analyses is the same. In DSHA and finite difference analysis, the characteristic seismic source is the failed Manner rift zone while in PSHA, failed Manner rift zone contribution appears to be the dominant one. 
A seismic hazard map for Sri Lanka is proposed considering the average PGA value at each location as given by the three analyses described above. Considering the range of average values obtained, two seismic zones were proposed as illustrated in Figure 4 as Zone 1 and Zone 2 having design PGA values of $0.1 \mathrm{~g}$ and $0.05 \mathrm{~g}$, respectively.

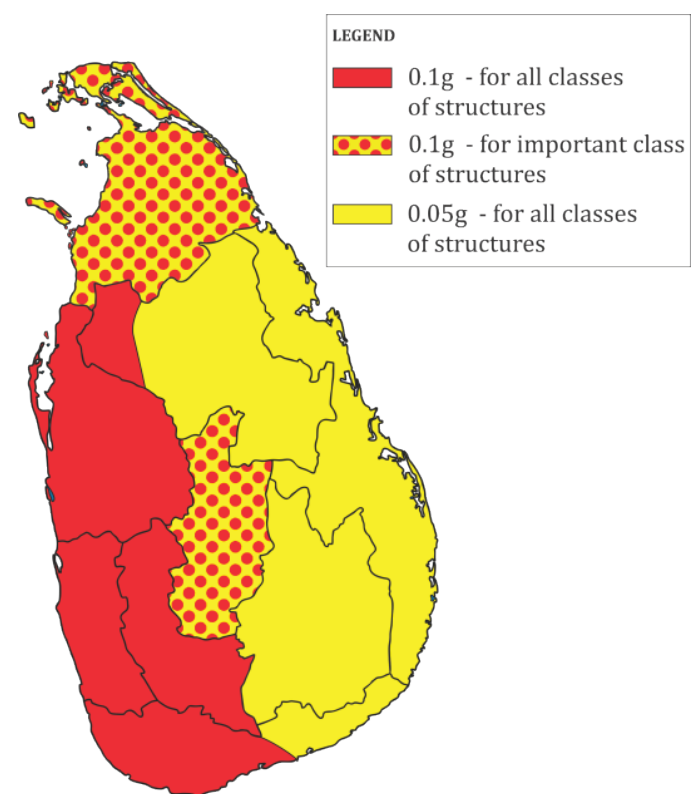

Figure 4 - Seismic Hazard Map for Sri Lanka based on Peak Ground Acceleration

The structural classes in all zones are identified as Class I (command centres, schools, hospitals, dams, public gathering places, ancient/cultural structures, highrise buildings etc.) and Class II (all the other engineered structures). In Zone 1, both Class I and Class II structures should be designed against the PGA $0.1 \mathrm{~g}$. In Zone 2, Class I structures should be designed against the PGA value of $0.1 \mathrm{~g}$ while Class II structures should be designed against $0.05 \mathrm{~g}$.

The proposed response spectra for all zones are illustrated in Figure 5 and the relationship given below.

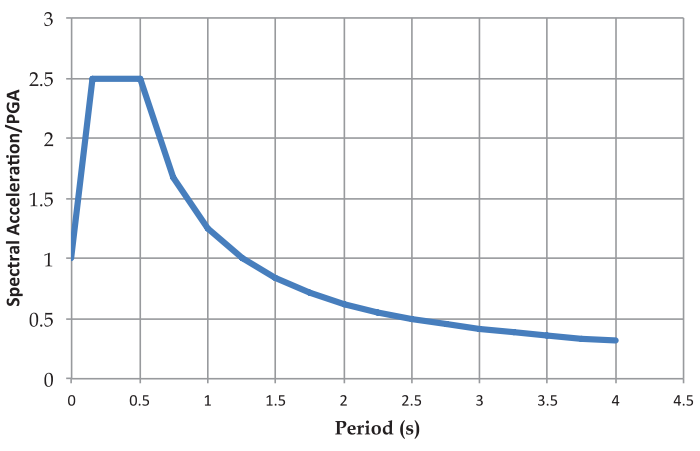

Figure 5 - Proposed Normalized Response Spectrum

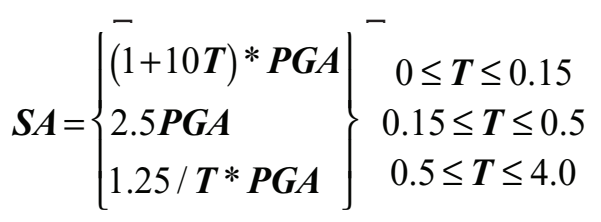

\section{Seismic Monitoring Programme}

In carrying out a comprehensive study on seismic status on Sri Lanka, recorded ground response at key points distributed throughout the island is required. The actual monitoring data at present are available only from three stations (Hakmana, Pallekele and Mahakanadarawa) of GSMB which are approximately aligned North-South through the centre of the island. The most vital region of western province does not have a single monitoring station. In the study described in this paper, lack of seismic monitoring data was a serious setback in trying to select appropriate attenuation relationships.

Therefore, there is an urgent need to establish a network of seismometers throughout the island so that the actual seismic response of any part of the island may be estimated to sufficient accuracy. The authors propose the seismometer configuration shown in Figure 6 for this purpose. The technical specification of seismometers should ensure that the frequency range of $0.1 \mathrm{~Hz}$ to $25 \mathrm{~Hz}$ is adequately represented.

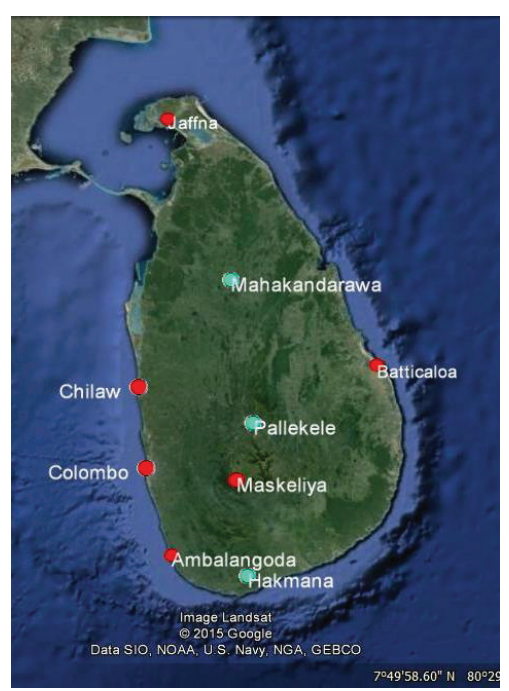

Figure 6 - Proposed Seismometer Configuration 


\section{Acknowledgements}

The authors wish to acknowledge the following:

- University of Peradeniya and Faculty of Engineering, Peradeniya for financial and other assistance.

- UNDP and DMC for partially financing this work.

- GSMB and Department of Meteorology for providing past earthquake records.

- All academic staff, and post graduate and undergraduate students of Earthquake Research Group, Faculty of Engineering, Peradeniya, for their contribution.

\section{References}

1. Abayakoon, S., "Seismic Risk Analysis of Sri Lanka", Journal of Geological Society, Sri Lanka, 1996, 65-72.

2. Abrahamson, N. A. and Silva, W. J., "Empirical Response Spectral Attenuation Relations for Shallow Crustal Earthquakes", Seism. Res. Let., Vol. 68, No. 1, 1997.

3. Baillie, P. W., Shaw, R. D., Liyanaarachchi, D. T. P. and Jayaratne, M. G., "A New Mesozoic Sedimentary Basin, Offshore Sri Lanka", EAGA $64^{\text {th }}$ Conference $\mathcal{E}$ Exhibition, Florence, Italy, 2002, 3-10.

4. Campbell, K. W., and Bozorgnia, Y., "NGA ground Motion Model for the Geometric Mean Horizontal Component of PGA, PGV, PGD and 5\% Damped Linear Elastic Response Spectra for Periods Ranging from 0.01 to 10 s", Earthq. Spectra 24 , no. $1,2008,139-171$.

5. Curray, J. R., "Sri Lanka: Is it a Mid-Plate Platelet?",J. Nara 31, 1984, pp 30-50.

6. Dissanayake, C. B., “A New Plate Boundary near Sri Lanka; Implications for Future Geo Hazards", Journal of the National Science Foundation of Sri Lanka, Vol 33(1), 2005.

7. Fernando, M. J. and Kulasinghe, A. N. S., "Seismicity of Sri Lanka", Physics of the Earth and Planetary Interiors, 44, 1986, 99-106.

8. Gitterman, Y., Zaslavsky, Y. and Shapira, A., "Analysis of Strong Motion Records in Israel", Proceedings of the Seventeenth Regional European Seminar on Earthquake Engineering, Haifa, Israel, 1993, 109-118.

9. Gunasekara, K. W., "First Earthquake in Sri Lanka", Sunday Observer, 2000, p. 34.

10. Jayawardena, U., A Study of the Engineering Properties of Sri Lankan Rocks. Journal of Institution of Engineers Sri Lanka XXXIV, 2001,720.
11. Kularathna, E. K. C. W., Pitawala, H. M. T. G. A Senaratne, A. and Weerasinghe, D., "GondwanaBreakup and Development of Sedimentary Basins in Sri Lanka". Proc. 31 st Annual Sessions of the Geol. Soc of Sri Lanka, 2015, p.6.

12. Kun-Sung, L. and Yi-Ben, T., "Attenuation Relationships of Peak Ground Acceleration and Velocity for Crustal Earthquakes in Taiwan", Bulletin of the Seismological Society of America, Vol. 95, No. 3, 2005, 1045-1058.

13. Menon A., Ornthammarath T., Corigliano M. and Lai C. G., "Probabilistic Seismic Hazard Macrozonation of Tamil Nadu in Southern India", Bulletin of the Seismological Society of America, vol. 1, no. 3, 2010, pp. 1320-1341.

14. Raghu Kanth, S. and Iyengar, R., "Estimation of Seismic Spectral Acceleration", Journal of Earth System Sciences 116, No. 3, 2007, 199-214.

15. Rana, M. S., Chakraborty, C., Sharma, R. and Giridhar, M., "Mannar Volcanics- Implications for Madagascar Breakup",7th International Conference and Exposition on Petroleum Geophysics, 2008, 358- 364 .

16. Reiter, L., "Earthquake Hazard Analysis: Issues and Insights", Columbia University Press, New York, NY, 1990.

17. Seneviratne, H. N., Perera, L. R. K., Wijesundara K. K., Dananjaya, R. M. S., Jayawardena, U. D. S. , Seismicity around Sri Lanka from Historical Records and its Engineering Implications, Journal of IESL, (under review), 2019.

18. Sreejith, K., Krishna, K., \& Bansal, A., Structure and Isostatic Compensation of the Comorin Ridge, North Central Indian Ocean, International Journal of Geophysics, 2008, 729-741.

19. Stepp, J. C., "Analysis of Completeness of the Earthquake Sample in the Puget Sound area, in Seismic Zoning", edited by S.T. Harding, NOAA Technical Report ERL 267-ESL30, Boulder, Colorado, 1973.

20. Thaldena, S., Perera, L. R. K. \& Prame, W., "Present Status of Seismic Monitoring and Risk Assessment in and around Sri Lanka",Proceedings of the $4^{\text {th }}$ International Conference on Structural Engineering and Construction Management. Kandy, Sri Lanka, 2013.

21. Uduweriya, R., Probabilistic Seismic Hazard Macrozonation In Sri Lanka.University of Peradeniya (Thesis Submitted for M.Sc Eng.), 2014.

22. Vitanage, P., "Seismicity in Lineaments - Impact on Engineering Structures, In Handbook on Geology and Mineral Resources of Sri Lanka", Second South Asia Geological Congress, GEOSAS - II, 1995, pp. 59-62. 
